\title{
Agnes S. Ku and Ngai Pun (eds), Remarking Citizenship in Hong Kong: Community, nation and the global city
}

Wai-man Lam

\section{CpenEdition}

\section{Journals}

Édition électronique

URL : http://journals.openedition.org/chinaperspectives/1853

DOI : $10.4000 /$ chinaperspectives. 1853

ISSN : 1996-4617

Éditeur

Centre d'étude français sur la Chine contemporaine

Édition imprimée

Date de publication : 15 avril 2007

ISSN : 2070-3449

Référence électronique

Wai-man Lam, « Agnes S. Ku and Ngai Pun (eds), Remarking Citizenship in Hong Kong: Community, nation and the global city », China Perspectives [En ligne], 2007/2 | 2007, mis en ligne le 08 avril 2008, consulté le 23 septembre 2020. URL : http://journals.openedition.org/chinaperspectives/1853 ; DOI https://doi.org/10.4000/chinaperspectives. 1853

Ce document a été généré automatiquement le 23 septembre 2020

(c) All rights reserved 


\title{
Agnes S. Ku and Ngai Pun (eds), Remarking Citizenship in Hong Kong: Community, nation and the global city
}

\author{
Wai-man Lam
}

1 This edited volume comes out at a timely moment, as Hong Kong is caught up in competing discourses (e.g., entrepreneurialism, democratisation, and nationalism) that make conflicting demands on the people, putting to a real test their ability to articulate their identity. Representing the joint efforts of a group of local scholars, the book debunks the theoretical meanings and local understandings of citizenship, and the repressive potential of the notion to be employed as a means of governance and exclusion in Hong Kong. The book contains a foreword by Bryan S. Turner, an introduction by the editors, and 12 chapters divided into three parts-a critique of the citizenship policies of the Hong Kong colonial and Special Administrative Region (SAR) governments, a critique of the exclusionary tendencies embedded in local mainstream culture, and an appraisal of challenges from local civil society to dominant conceptions of citizenship.

2 Chapter 1 by Denny Ho reconstructs the three major strategies of Hong Kong's colonial governance (i.e., the hierarchy of command, the anarchy of exchange, and the heterarchy of self-organisation), and argues that these strategies help to explain the underdevelopment of citizen rights during the colonial era. As suggested, the political rights of the people were confined, civic rights were narrowly defined as market rights, and social rights were restrictively promoted as familial ethics to cultivate people's self-reliance. Based on historical evidence, Iam-chong Ip reveals in Chapter 2 that the provision of public housing by the colonial government did not emerge from a concern for expanding social rights, nor was it related to other considerations, such as the opportunity cost of remaining inactive on the squatter problem. Instead, it was motivated by the colonial regime's anxiety to maintain public order, and public health 
(or the sanitary syndrome that traces its origin back to Britain since the midnineteenth century). In Chapter 3, Thomas Tse unravelled the politics of civic education during the political transition and the SAR era. Civic education was characterised by a process of re-nationalisation that, ironically, ran parallel to a process of de-politicisation. The latter aimed at containing the influence of critical and democratic discourses. Globalism was another major theme of civic education, which, however, has made it even more difficult for the people to deal simultaneously with the contradictory demands of being global and patriotic. Chapter 4 by Anita Chan examines the educational reforms since the 1980s and the challenges they pose to the embedded notion of ideal citizen/student. Based on interviews with female students studying in different bands of school, she criticises the notion's gender and class bias for its emphasis on competition, entrepreneurialism and individualism, and its unequal openness to male and female students, as well as to female students from different social classes.

3 In Chapter 5, Hon-chu Leung analysed the politics of social membership by reviewing immigration policies from the 1950s onwards. As suggested, the policies have helped to stigmatise mainland migrants as an excluded group and a burden to the society. The fact that the restrictions on the eligibility of newly reunited families (families with recent mainland migrants) for public housing were not relaxed until 2000 is a good example. Chapter 6 by Barry Sautman criticises Hong Kong as a semi-ethnocracy where a not-so-rigid but omnipresent ethnic hierarchy with a tripartite structure existed-the ethnic Chinese elites as citizens, the new mainland migrants as well as the European, American, and East Asian expatriates as denizens, and South Asians as "margizens". Based on interviews with new female migrants, Chapter 7 by Ngai Pun and Ka-ming Wu criticises the narrative of Hong Kong as a global city as actually signifying global colonialism. In this hegemonic narrative, women migrants from the mainland were often classified as bad citizens who had been displaced from a job market that increasingly discarded manual labour, and emphasised information and knowledge. Chapter 8 by Agnes $\mathrm{Ku}$ examines the formation and development of the discourse of law and order, created primarily for the purpose of colonial governance, and a related, but more liberal, discourse of the rule of law, that emerged during the political transition as society became more rights-conscious. The two discourses have been at loggerheads since 1997, as reflected notably by the Public Order Ordinance dispute and the Article 23 controversy.

Chapter 9 by Lai-ching Leung criticises the claimed gender-neutral assumption of the concept of citizenship, and suggests that the understanding of citizenship should incorporate a gender analysis and the diversity of women's concerns in citizenship debates. Local women's movements have played an important part in struggling for women's full citizenship in the areas of work, taxation, social welfare, political rights and participation, sexual violence and media culture. Chapter 10 by Day Wong analyses the development of local homosexual rights movement, and argues that the movement has appealed to essentialist notions of homosexual identity, e.g., homosexuality as innate nature, and the view that homosexuals are, like heterosexuals, law-abiding, economically productive and respectable members of society. Nevertheless, the moment of transgression within the movement in recent years has manifested the antinormalisation strategies adopted by some activists who promote the difference of a homosexual identity. In Chapter 11, Po-keung Hui criticises the notion of economic man and qualified economic citizen prevalent in Hong Kong, and evaluates the pros and 
cons of community life. He discusses the possibility of a communal economic subject, a kind of alternative citizenship, which could realise both communitarian and individualist ethics, and evaluates a community economy project, identified as an attempt to achieve similar goals. Chapter 12 by Alvin So provides a comparative perspective on the transformation of types of citizenship in Greater China at different periods. As suggested, the factors of state policies, nationhood, market, and existing class structure all play a part in the making of citizenship. The introduction by $\mathrm{Ku}$ and Pun provides a chronological perspective, yet another interesting way to comprehend the multiple themes of the book. It traces the advent of the notion of colonial citizenship from the 1960s to the 1980s, and further examines its changing meanings under the influence of a neo-liberal discourse and a globalisation narrative.

5 Some themes are common to several chapters. Most of them make strong critiques of hegemonic discourses, e.g., the conceptions of economic man and enterprising individual, and the narratives of globalisation and cosmopolitanism. In the same vein, most of them are critical of the promoters of such discourses, including, for example, the colonial and the SAR governments, and the people of Hong Kong (i.e., who have embodied the mainstream culture). Although some chapters focus on governance while others centre their discussion on civil society, they all demonstrate a concern for marginalised people, and attempt to speak from the margin. All of the chapters demonstrate theoretical sophistication and original empirical research. They attempt to merge theory into real politics analysis although not every chapter is successful in this. A few show their post-modern colour by attempting to bridge the gaps between dichotomised concepts-one example is the concept of a communal economic subject that merges the advantages of both communitarian and capitalistic individualism-and this makes them truly impressive both academically and empirically speaking. The fact that the book has tried to include multiple focuses and targets of analysis makes its theme less outstanding, but reading it is certainly a rich and manifold experience. Overall, this is a book of great value in terms of its research agenda as well as theoretical and empirical contributions. 